\title{
AFTER THE END OF "LITTLE MOSCOW": MEMORIES, (RE)CONSTRUCTION, AND APPROPRIATION OF SPACE IN WÜNSDORF
}

\author{
Christoph Lorke \\ Department of History \\ Westfälische Wilhelms University, Münster, Germany \\ e-mail: christoph.lorke@uni-muenster.de
}

\begin{abstract}
This article focuses on the context and lasting consequences of the withdrawal of the Russian troops from the small town of Wünsdorf in East Germany (Brandenburg region) in 1994. The headquarters of the high command of the Soviet forces in Germany had been located in Wünsdorf since 1954. The locals lived in close proximity to the Russians. In the German Democratic Republic, the (limited) real and imagined encounters, interactions, and perceptions of the "other" were highly determined by traditional images, and were most likely influenced by the tabooed official discourse of "occupiers" vs. "friends". This ambivalent potpourri of different memorial dimensions has strongly shaped negotiations of the past and remembrance of the transition period (1989/1990-1994), as well as of the post-Soviet/Russian phase up to the present. By analyzing individual and collective modes of handling a problematic and highly conflictual military force, as well as the German Democratic Republic's past, different ways of (re)constructing and appropriating the post-military space become apparent.
\end{abstract}

Keywords: Cold War, German Democratic Republic's past, German reunification, identity, (contested) memory, military heritage, otherness, space

On August 31, 1994, Matvei Prokopevich Burlakov, the last Commander-inChief of the Group of Soviet Forces in Germany, reported to President Boris Yeltsin: "The intergovernmental treaty regarding the conditions of the temporary residence of Russian troops and the withdrawal modalities are fulfilled.... Today was the last day of the past" (König 2010). According to Article 4 of the "Two Plus Four Treaty" ("Treaty on the Final Settlement with Respect to Germany", September 12, 1990), the Soviet Union was obliged to withdraw its troops stationed in East Germany within four years, i.e. by the end of 1994. On August 31, the largest relocation of troops during peacetime in history, which brought about an unprecedented demilitarization of land and property, was realized four months earlier than originally planned. The Western Group of 
Forces ${ }^{1}$ was considered an elite unit of the Soviet Army and included 550,000 people, of whom 380,000 were members of the army and 170,000 were civilians (among whom there were 90,000 children). The troops were based in more than one thousand locations all over East Germany. The country was considered an immensely important geostrategic, military, and, not least, symbolic-political forward post, located right on the Iron Curtain. ${ }^{2}$ There were many important military bases ${ }^{3}$ and many of them ${ }^{4}$ in the immediate vicinity of East Berlin. One of the main reasons for this military cordon was to be ready to quell potential riots, as happened when the Group of Soviet Forces in Germany helped suppress the Uprising of 1953 in East Germany (Fig. 1).

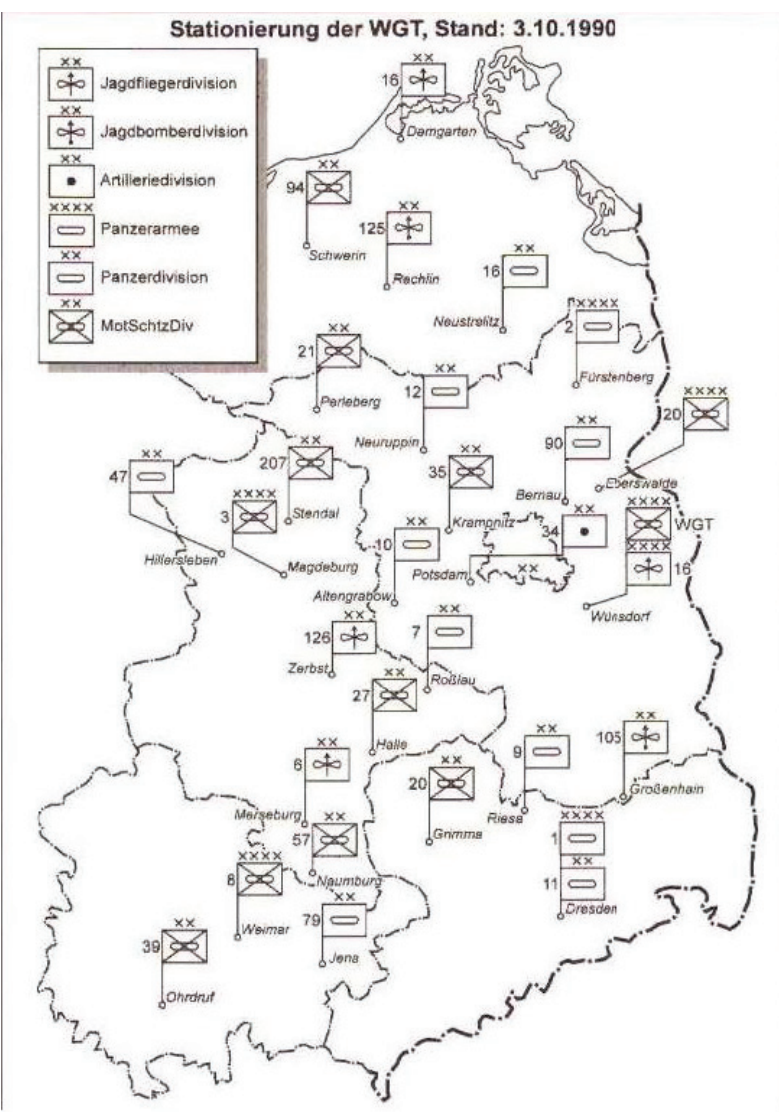

Figure 1. Western Group of Forces in the German Democratic Republic, October 3, 1990 (Naumann 1996 [1993]: 345). 
Figure 2. General Matvei P. Burlakov and Manfred Stolpe. Wünsdorf, June 11, 1994 (Gehrke 2008: 74).

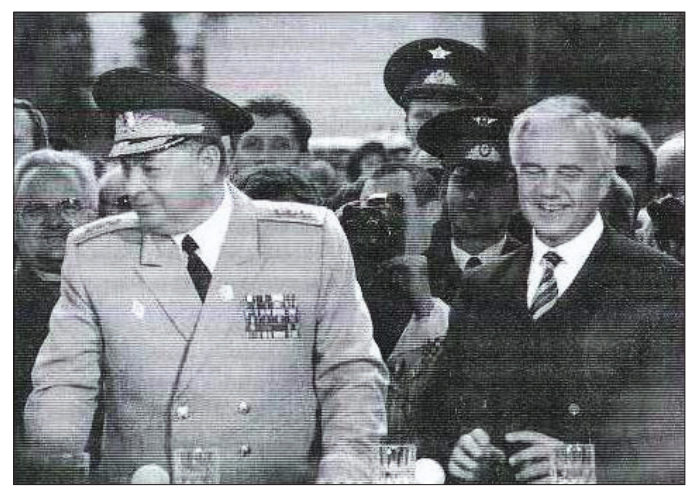

By far, the largest number of troops were based in Wünsdorf. Since 1954 the headquarters of the high command of the Soviet Forces in Germany had been situated in this small town, less than fifty kilometers south of Berlin. Wünsdorf was a divided - military and civilian - location during the Cold War. The figures vary, but it can be assumed that between 40,000 and 70,000 soldiers and civilians were living and working there. Thus, the place was an immensely important strategic outpost and, because of its location close to the Cold War's geographical border, the Western Group of Forces were regarded as the "chosen ones", "the proud and favorite children" of the entire Soviet Army. ${ }^{5}$

When the last soldiers left in 1994, a 600-hectare area with tens of thousands of rounds of ammunition and explosive ordnance remained, including almost 680 buildings, 45,000 cubic meters of rubbish, waste oil, paint, chemicals, batteries, used tires, and asbestos, as well as 404 cats, twenty-six dogs, one goat, and one wild sheep (Kaiser \& Herrmann 2010 [1993]: 199-200). In the common parlance of the locals, the military area of Wünsdorf was generally known as "Little Moskwa" or the "Forbidden City" (Verbotene Stadt). With few exceptions, natives were not allowed to enter this zone and the whole settlement, including the daily life of the Soviet families, was taboo. Nevertheless, living in close proximity led to the fact that the Russians were omnipresent in the daily lives of the German residents before the transition period (1989-1994). The result was the emergence of conflictual situations and memories, which - as has been discussed regarding other examples of Soviet military bases in the German Democratic Republic (GDR) - have often lasted until the present time (e.g. von Wrochem 2003). As a consequence, noteworthy tensions between the collective and communicative memory, on the one side, and the public commemorative culture, on the other, could be observed (for definitions of the collective and communicative memory, see Assmann 1997 [1992]; Welzer 2002; Erll 2005). By far the largest base of Soviet/Russian soldiers prior to 1994, the military 
district of Wünsdorf appeared in many respects to be a "non-place", with its distorted, inconclusive relationship between history and identity (Augé 1992).

This article discusses the memorial dimension of the Soviet/Russian past in Wünsdorf, as well as the symbolic (re-)construction and the collective and individual appropriation of this particular space after the Soviet/Russian withdrawal in 1994. By analyzing hegemonic forms of public (primarily involving politics and the media) and individual remembrance of the "foreign" Soviet/ Russian past within the (post-)socialist GDR society (Obertreis \& Stephan 2009), the social, discursive, and symbolic (re-)shaping of space and its symbolic (pre-)determination can be illustrated (Assmann 2009; Keller 2016). Focusing on these aspects, Wünsdorf exemplifies double-layered, closely intertwined negotiations with a conflictual "problematic" past with regard to 1) the GDR as a whole and 2) the Soviet/Russian occupiers as "foreign" forces. This contribution deals with the different modes of managing conflictual and dissonant heritage in the individual and broader political and public dimensions (Tunbridge \& Ashworth 1996; for the relation between cultural heritage and war, see Sörensen \& Viejo-Rose 2015) by focusing on the following questions: how did the long-standing presence of the "foreign" shape the remembrance of Wünsdorf's recent past? How do certain layers of memory interact with each other? What kind of "master narratives" of that time were (and are) dominant, and why? How can German and Russian perspectives be integrated when dealing with the still "smoking" past (Tuchman 1964)?

To answer these questions, I analyzed research, scholarly and popular publications on the matter, and media narratives since 1990. Furthermore, in spring and summer 2016, I conducted twenty interviews with German contemporary witnesses. I contacted the interview participants through a press call that was distributed via local media. ${ }^{6}$ The call explicitly asked for witnesses who remembered not only the process of withdrawal but also the time before. Thus, most of the interviewees were - and, in most cases, still are - local residents. The guided telephone interviews usually lasted one or two hours. ${ }^{7}$ The oldest interviewee was born in 1929, and the youngest in 1954. This range allowed for further insights regarding the relationship between generations and space, ${ }^{8}$ its different symbolic constructions, performances, and acquisitions, as well as the generational temporalization of the space in question (Grothusen 2014). Significantly, nineteen of the twenty people who answered the call were male; this obvious gender imbalance requires explanation (Leydesdorff 1996). It seems that the topic of (military) history and its aftermath is much more interesting for men. Due to traditional, dualistic gender stereotypes and corresponding attributions regarding "male" and "female" spheres of interest and awareness, it is also possible that men consider themselves "more important" and "more 
competent" witnesses of this time period. The tabooed topic of rape also may have influenced the willingness of people to answer the call (von Wrochem 2003: 67-68). ${ }^{9}$ Thus, the "voluntary" aspect of the call significantly distorted the sample. However, this article does not claim to be a representative survey, but rather a glimpse into the widely encountered patterns of memory and their presence today. Therefore, a gendered perspective on the story is built into the study. After a quick glance at the military history of Wünsdorf in the twentieth century, the paper discusses the circumstances and forms of remembrance of the process of withdrawal from today's perspective. In the last chapter, I will outline the most common ways of dealing with the Soviet/Russian past in the context of the "conversion" after 1994.

\section{FROM WÜNSDORF TO ВЮНСДОРФ AND BACK: A GARRISON TOWN AND ITS MILITARY HERITAGE}

The history of Wünsdorf as a military site is suspenseful, as well as full of fractures and new beginnings (for an overview, see Kaiser 1998). Wünsdorf was a small village with less than 900 inhabitants when an Infantry School was opened in 1910. During World War I the first mosque on German territory was built there at the request of the Office for Foreign Affairs, when a camp for prisoners of war was opened in Wünsdorf. The "Half Moon Camp" housed up to at least 15,000 Muslim prisoners of war until 1918, mainly Tatars, Indians, Moroccans, Algerians, and Senegalese. After the end of the war, the camp served as a shelter for Russian emigrants, mostly Muslim Tatars, many of whom had decided not to go back to their home country. The camp was finally closed in 1922 and the mosque was torn down two years later because of dilapidation (Abdullah 1984: 18-20; Höpp 1997). During the Third Reich, the area served as a military gymnastics school, and was used as a training camp for athletes to prepare for the Olympic Games in Berlin in 1936. There was an enormous barracks area, a military training area, and a firing range. Beginning in 1938, the headquarters of the Supreme Command of the Armed Forces (Oberkommando der Wehrmacht) was situated in Wünsdorf. On April 20, 1945, the area was occupied by Soviet troops; the command staff and Marshal Georgy Zhukov stayed there during the final battle of Berlin. Beginning in 1946, the area was used by the 1st Belorussian Front.

In February 1954, the place became the headquarters of the High Command of the Soviet Forces in Germany, and the Soviet military housing rapidly expanded: 175 local families, 800 people in total, had to leave their houses, apartments, and property, and were resettled to make way for the Soviet Army 
and its personnel (Kaiser \& Herrmann 2010 [1993]: 138). Elderly citizens still remember this time as a deep disruption of their personal mobility and lives. ${ }^{10}$ At this point, the highway F $96^{11}$ - by then the longest highway within the GDR and the most important direct connection to its capital, Berlin - was closed to transit traffic until 1994, dividing Wünsdorf into two. Ordinary people who did not have authorized transit permission (propusk) had to make a laborious detour of more than ten kilometers (Fig. 3).

Henceforth, the military area was closed to GDR civilians, and even the Socialist Unity Party of Germany's (Sozialistische Einheitspartei Deutschlands, SED) ruling elite was not allowed to enter until 1960, when Willi Stoph, the then Minister of National Defense and subsequently Deputy Prime Minister of the GDR (1964-1973), paid a visit to the troops. Most GDR citizens were not aware of the existence, size, and importance of Wünsdorf as a military site and a control center of the Soviet Army during the Cold War. From there not only was armored protection organized during the construction of the Berlin Wall under Marshal Ivan Konev, but also aviation security for the entire GDR airspace was guaranteed. Both the suppression of the Prague Spring in 1968 and the change in the GDR government in 1971, when Walter Ulbricht was replaced by Erich Honecker as the General Secretary of the Central Committee of the ruling

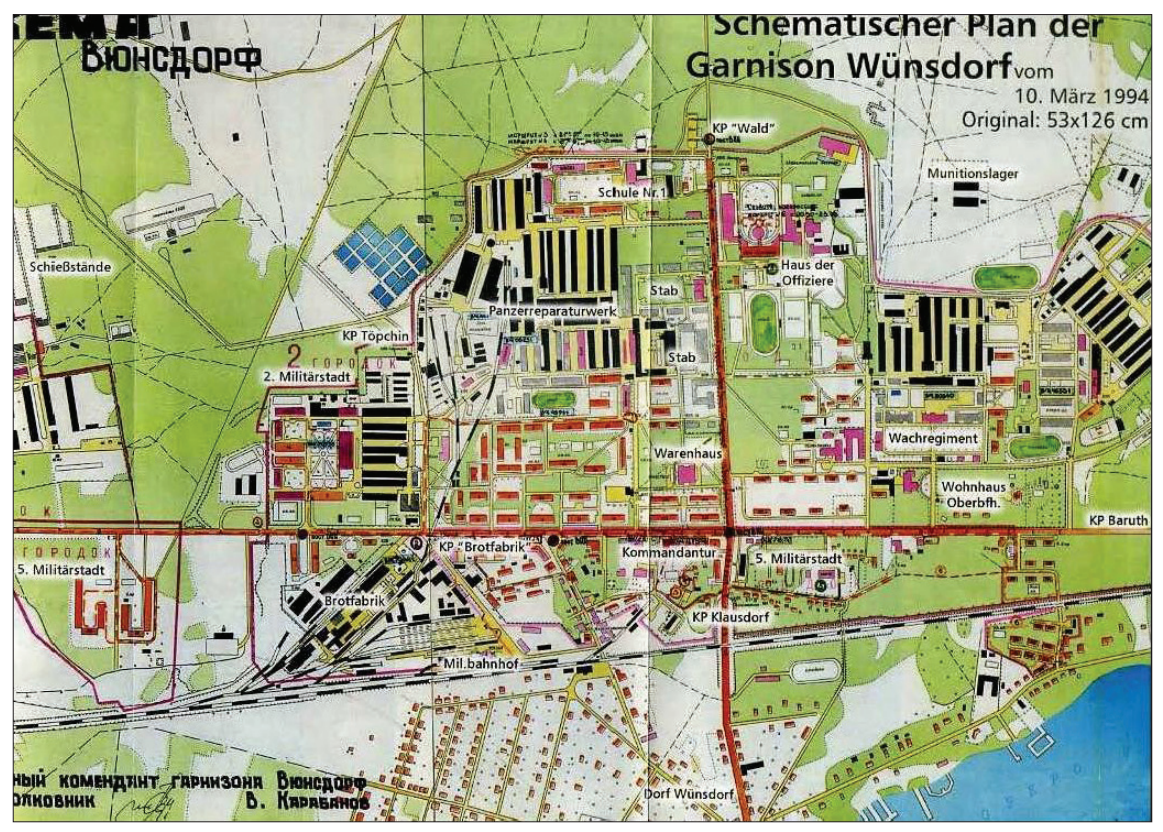

Figure 3. Map of Wünsdorf. Garnisonsmuseum Wünsdorf, March 10, 1994. 
party, were coordinated and commanded from Wünsdorf. Doubtless, this place could be regarded as the fist of Soviet policy in the GDR (Kowalczuk \& Wolle 2010: 126; for the circumstances of the occupation, see Satjukow 2008; for the broader context, see Loth 1998). There was a daily military train to Moscow for Soviet soldiers and their families at 8 pm every evening, which departed from what was called Russen-Bahnhof ('Russians' Station').

The closed doors of the "Forbidden City" - also a popular term to describe other Soviet military places in the GDR, such as Hillersleben, Neuruppin, Naumburg, and Weimar - stimulated speculation, and not only in regard to the quantity of troops and civilians stationed in Wünsdorf, which was a proper city with schools and kindergartens, medical care, a theater, sport facilities, and its own hairdressers and shops. In this context, the ideologically justified and politically imposed "friendship" between the occupants and the natives was full of suspense and was decisively influenced by 1) the former ideas of the highly ideologically and racially connoted image of the "Bolsheviks" and 2) the perception of the Russenkasernen ('Russian barracks') in daily life. As the historian Silke Satjukow asserted (2004: 237-240; 2005; 2009: 57-58), many residents did not perceive the barracks as places of safety, but rather of unpredictability and hidden danger due to unpleasant noises and odors, incoming and outgoing tanks and helicopters, damage along public roads or agricultural areas, explosions, aviation noises and resulting impairments. Furthermore, because of traffic accidents, "unnatural deaths", brawls in restaurants, robberies, and sexual attacks, the barracks became places of danger and foreignness (Behrends 2003; Müller 2011: 163-189). This refers to specific modes of inclusion, exclusion, and fixation of the "foreign" within a certain space, in this case the "Forbidden City" (with reference to Georg Simmel: Geenen 2002: 223-239).

On the other hand, the forbidden zone also had considerable appeal, which the Wünsdorf locals experienced notably in the area of consumption. It is significant that almost half of the interviewees mentioned several aspects which referred to a well-functioning partnership of convenience, especially in later decades. The special Russenmagazine ('Russians' stores') sold many sought-after products. Party functionaries and a few people who were working within the restricted area were holders of propusks, entry tickets into the restricted area, and they described how they benefited from certain privileges. Popular, but usually very rare products, such as building materials, Czech beer, Hungarian ham, tropical fruits, tinned fish, confections, and even smoked eels from the Baltic sea were sold, and thus represented another dimension of encountering the "foreign": culinary delights and accouterments. In retrospect, such ex-post constructed imagined behavior patterns could obviously also evoke the aftertaste of unjustified, "conspicuous consumption" (Veblen 1899), which is very evident in 
the example of Gerhard Dombritz (born in 1942). He was a local political activist in the 1990s and described himself as "not a Russian whisperer". Dombritz stated, "more by hearsay than by personal experience", that, in his memory, the lifestyle of the officers was exorbitant. Furthermore, the high-ranking officers' food and supplies were even "more snobbish"12 than in the secure housing zone for leading functionaries in Wandlitz, about thirty kilometers northeast of Berlin. Senior party members of the Socialist Unity Party of Germany lived there; the area remained off-limits to ordinary East Germans until 1990.

This statement illustrates that, in terms of more than boarding and lodging, the interviewees remember a massive discrepancy between German and Soviet higher ranks. In addition, the differences and prosperity gaps between the military ranks - and thus, inevitably, between the locals and the lower ranks - were also immense. Hence, there was self-ghettoization of the Soviet troops, which was not surprising since it helped to limit the soldiers' "Western experience", especially with regard to consumption. In the eyes of many ordinary Soviet soldiers and in comparison with their own situation after the end of World War II, the Germans lived "off the fat of the land" (Satjukow 2004: 225-249). Thus, rigorous spatial isolation, poor accommodations, low salaries, strict regulations regarding contact with the locals, and prohibitions against fraternization were implemented by the military administration, as those seemed to be the safest means of avoiding disciplinary violations (Bassistow 1994: 46-48).

However, in the case of Wünsdorf, as everywhere else, German-Soviet contact could never be prevented entirely, exceeding the usual scope of highly formalized, prepared and stage-managed official encounters, and not only because of the approximately 1,000 Germans who worked in the garrison at the end of the GDR; instead, "friendships" or "friendly relations" - terms frequently used in the interviews - and even a few love affairs developed. Nonetheless, the Waffenbrüderschaft ('comrades-in-arms') were, just like everywhere else in the GDR, apparently limited to the officer corps (Müller 2005: 128-132). While the lower ranks lived in comparatively meager accommodations - although flush toilets, washbasins, and showers were not standard in the Soviet Army - service in the GDR forces was particularly advantageous for officers and generals: between 800 and 1,000 marks per month, a family allowance of up to 250 marks, and a significantly better range of products available. Four or five years in the GDR forces made it possible to procure goods and clothes, and even to save some money. In short, service in Wünsdorf was regarded as an honor for the "favored few" Soviet Army soldiers, in particular in terms of living standard (Bassistow 1994: 49-50; Kaiser \& Herrmann 2010: 144). For the locals, the image of Wünsdorf was strongly marked by the presence of soldiers. Hence, they resigned themselves to living in a city of "occupiers"; for many, living 
with the Russians became a part of the everyday routine, eventually not only in Wünsdorf, but in other Soviet military bases, too. This routine was suddenly and unexpectedly shaken by the fall of the Berlin Wall in the autumn of 1989 .

\section{TIMES OF CHANGES, TIMES OF UNCERTAINTY: THE INTERIM PHASE, THE WITHDRAWAL, OLD AND NEW CONFLICTS}

In many respects, the early 1990s in reunified Germany can be characterized as a transition period, although the break was usually much more abrupt and intense for East Germans than for West Germans (Danyel 2015). The presence (and later, withdrawal) of the Russian troops is one of the many different, overlying, and partially interwoven passages between the "old" and the "new". After the fall of the Berlin Wall and the reunification of Germany in October 1990, the Russian military command initially regarded the desire of many Germans for unity, freedom, and sovereignty as ingratitude. Little by little, understanding grew, while at the same time concerns increased with regard to the period after the withdrawal. Uncertainty and psychological stress among the soldiers increased (Arlt 1998: 619).

The majority of the East Germans, however, welcomed the withdrawal as a "second" or even "real liberation", since now there was a way to express longrepressed sentiments. Sensationalist press articles and simple stigmatizations supported a shift in liability, a deflection of responsibility regarding the failures and the end of the GDR, which served as mental exculpation. The Russians, who were previously praised, were in this emotionally charged phase defamed as "uncivilized occupiers" (Satjukow 2009: 62) and thus represented the "other", anti-civilization, now in contrast to the West. Emphasizing a narrative of wild upheaval, the media landscape was full of lurid articles dealing with crime, corruption, and immorality, half-barbaric behavior, a shadow economy, mafia-type actions, bribes, the flourishing "black market", drug trafficking, unexplained murders, and contract killings. The "flogging" of all manner of things - including food, cars, and guns - from which both the Russian and (West and East) German traders had benefited, was one of the main topoi. Wünsdorf was especially pointed out as an important trading center. Other sensationalist comments involved the Russians' lax handling of environmental problems. ${ }^{13}$ By appealing - both intentionally and unintentionally - to anti-Soviet prejudices and feelings, these media narratives enjoyed great popularity among the reunified German public.

These discourses seem to have strongly influenced, shaped, and strengthened individual perceptions and imaginations. The same applies to the debates about 
the GDR as a "Stasi state" or Unrechtsstaat ('illegitimate state'), which for many East Germans involved a symbolic general devaluation of their biographies and overlapped with the discourses regarding the Russians (for an overview, see Großbölting 2010; Kollmorgen 2010; Sabrow 2012). After 1990, opinions and prejudices regarding the Russians, which had been taboo due to the propagandaimposed glorification of the Soviets as heroic liberators, were able to emerge directly. It seems that very soon after 1990 many East Germans - and thus, of course, Wünsdorf locals - regarded the Russians as a complementary element of the new society, which helped to strengthen a new specific, occasionally ostentatious, and confidently performed East German sense of unity (Satjukow 2009: 65). In contrast, others saw the derogatory judgments regarding the Russians as personal attacks on themselves. Provided this brief sketch of a conflictual and contested scenario, many Wünsdorf residents remember feeling joy and relief, as well as compassion and uncertainty, when the Russian troops left. Probably because they knew that the end of the transition period was near and, at the same time, recognizing the importance of the armed forces to the local economy, they felt a certain empathy with the soldiers. Local businessmen in particular were even very sad, as Günther Heisig (born in 1933), at that time the owner of a shoe store, remembered..$^{14}$

From a source-critical point of view, personal statements about the "Soviet occupiers" involved problems: whether the statements served as a subsequent smoothing, or reflected actually existing sentiments, varied from individual to individual. Quite a few respondents' descriptions of their experiences with Soviets/Russians were most probably affected by contemporary stereotypes or their opinions on present-day Russia. However, in Wünsdorf - as in many other military bases in East Germany - concerns about the remaining soldiers did arise, and with alarming openness. There were occasional demands, such as "Civilian Russians Go Home", "Leave, Russian Parasites" or, as residents painted in Cyrillic on the road to the department store: "Get Out, You Bastards". ${ }^{15}$ The environmental damage - in the end, a cost borne by the Federal Republic of Germany - in all likelihood strengthened such negative sentiments.

According to Arnold Klein (born in 1954), who felt melancholy after the withdrawal, thefts and vandalism were the order of the day, ${ }^{16}$ and even physical assaults targeting soldiers and their families were observed. Even though these were only scattered incidents, these years were characterized by wildness, confusion, and a new form of uncertainty. Ilse Bollman, who had worked for more than twenty years inside the "restricted zone", said with regard to crime and the attacks: "During this period, you could trust no one - neither Russians nor Germans". ${ }^{17}$ Both Winfried Bläse (born in 1950) and Bernhard Michel stated that after the withdrawal, Wünsdorf was dead, an utter ghost 
town. ${ }^{18}$ When the rising unemployment and the closing of businesses became more evident - after the initial phase of euphoria and relief - very quickly an atmosphere of disillusionment and uncertainty developed among many locals. They considered the period after 1994 a standstill or even a decline, and thus mourned in many respects the passing of the good old days. ${ }^{19}$ It is obvious that the assessments of those days were highly linked to the respective individual's perception and valuation of the Soviet/Russian troops.

A closer look at the "other" side reveals further insights: for the Russian soldiers, the shift was apparently even more radical. The psychological effects of the ideological collapse and the instability in their home regions, and the pronounced feeling of being unwanted and unwelcome guests undermined selfconfidence: for many of the soldiers, withdrawal meant social decline. They felt like "beaten winners", as the last Minister-President of the GDR, Lothar de Maizière, stated in Moscow in spring 1990. Due to the insecure future, a significant proportion - according to estimates, up to one-third - of all returned families split up (Locke 2014).

Another serious problem was the slow process of the housing program. Despite the eight-billion-mark support by the Federal Government, there were significant delays. Although 45,000 apartments were built in Russia, Ukraine, and Belarus between 1992 and 1996, 50,000 families had no suitable housing after their return (Foertsch 1994: 125-127). Preparing for their withdrawal, many soldiers bought household appliances, technological items, or second-hand cars in order to sell them in Russia. There were rumors of secret arms sales according to recent surveys, 81,000 tons of ammunition went unaccounted for (Kaiser \& Herrmann 2010 [1993]: 184) - and Kalashnikov for used car swaps (e.g. Liebold 1991). "Taking everything that was not nailed down" was a phrase often mentioned in the interviews. In contrast, Heinz Bremer (born in 1936), who generally pleaded for an "objective analysis" of those developments, expressed an explicit warning against a derogatory attitude toward the situation, especially by those who did not know the actual living conditions in their home countries very well. ${ }^{20}$

The official farewell celebration, which was initiated and orchestrated by the Russian commanders, was intended to symbolize the departure of Russian troops from all of Germany, and to make people forget any negative feelings. Thus, the narrative Heimkehr / Abschied in Würde ('Leave in Dignity') was established in bilateral contracts after 1990 in order to express caution, gentleness, and tact (Burlakov 1994; Foertsch 1994; Nawrocki 1994; Abschied in Würde 1994). However, even though the withdrawal was performed in a calm, formal atmosphere that could be considered a "logistical tour de force" (Gießmann 1992: 177-209; Kaiser \& Herrmann 2010: 182; for a meticulous chronological 


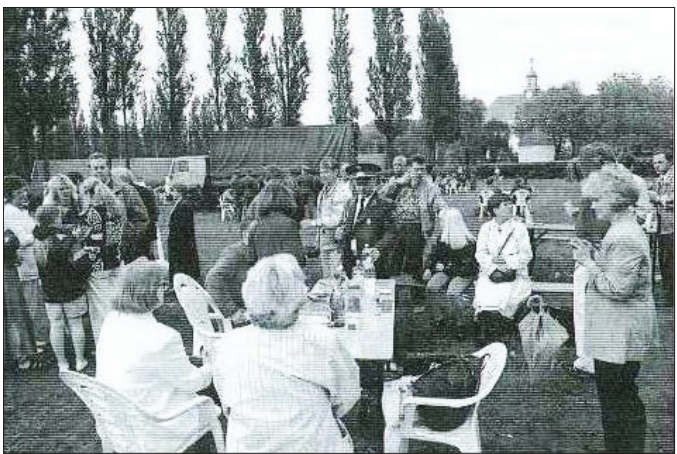

Figure 4. Open house in Wünsdorf, June 11, 1994. Civilians were given the opportunity to observe the 'inner life' of the former "Forbidden City" (Gehrke 2008: 74).

summary of the withdrawal, see Hoffmann \& Stoof 2013), the aim of a "worthy" final stage of the Russian troops in Germany was only partially successful. The farewell parade in Wünsdorf, broadcast live by the regional broadcaster Ostdeutscher Rundfunk Brandenburg (ORB) ${ }^{21}$ was an essential part of this project, and was meant to symbolically prove the new openness of the Russian troops. On June 11, 1994, thousands of people had the opportunity to observe the "inner life" of the former "Forbidden City". For an entrance fee of ten marks, most of the citizens of Wünsdorf could visit the inside area for the first time. In his farewell address, the Prime Minister at the time, Manfred Stolpe, thanked the Russian troops for their prudence in 1989 and 1990. "It was a folk festival, and everybody celebrated. We ate cake

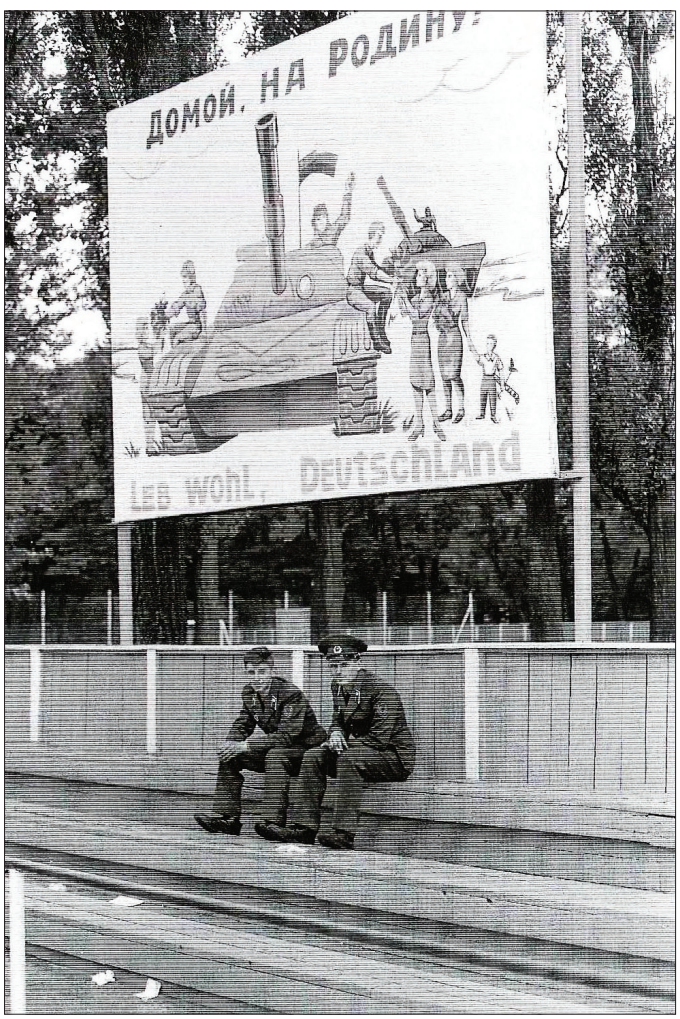
and solyanka, drank vodka, and I had tears in my eyes", Winfried Bläse, one of the interviewees, remembered. This observation sheds light on the perception of "foreign" food culture in the town with respect to the Russian "tradition" and its consequences of inter-cultural learning dynamics (for West Germany, see Möhring 2012). Born in 1950, Bläse had grown up with the Russians, and he and his family profited greatly from them. The period between 1990 and 1994 was, he added, "the best time of [his] life", ${ }^{22}$ not

Figure 5. The bilingual poster reads, "Homeward, to the motherland. Farewell, Germany!” Wünsdorf, June 11, 1994 (Gehrke 2008: 75). 
despite but rather because of the presence of the Soviet/Russian forces. The celebrations in summer 1994 were regarded as the symbolic culmination of a felicitous relationship.

While these festivities were remembered positively by some, they also evoked serious political inconsistencies, and this still plays a key role in many memories: on that day, politicians from the Brandenburg state government came, but no representatives from the federal government or the federal armed forces were present (Kampe 2009: 49). In most of the interviews, people mentioned their disappointment, describing how they interpreted this as a sign of arrogance, and thus a downgrading of the Russian troops by the Bonn government, which seemed to reflect an ongoing lack of respect for the Eastern Germans' lives, as well as for the Russian Army. Moreover, the Russian withdrawal was accompanied by different, either intended or unintended, forms of "tactlessness", misconceptions, and friction. One prominent example is the appointment of Hartmut Foertsch as the director of the liaison organization between the German and Russian Armies. Foertsch's father Friedrich had served as a general during the 900-day siege of Leningrad in 1941.

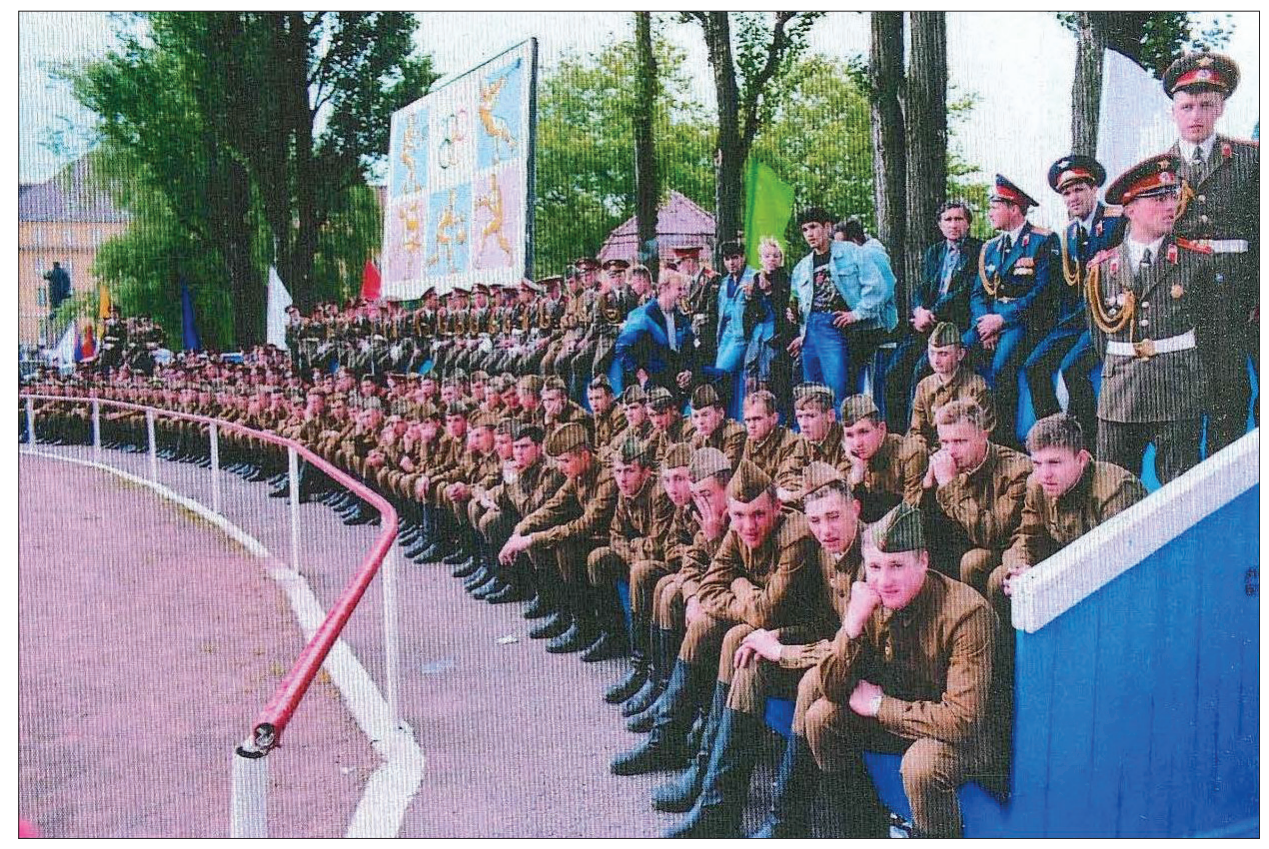

Figure 6. Spectators at martial arts performances in Wünsdorf. June 11, 1994 (Gehrke 2008: 61). 
In meetings with representatives of the German Federal Armed Forces (Bundeswehr), which were doubtless full of clear and mutual reservations, quite a few of the Russian commanders were dismayed at the fact that their property and goods had become (almost) valueless. Walter Meining, who took part in the negotiations with the Soviet Army, described the meetings as full of arrogance on the part of the Germans, "with only a few exceptions": Meining, for example, mentioned General Werner von Scheven, the Chief Officer of the Federal Armed Forces in the newly-formed German states, as a very fair-minded person who dealt with the Russians "eye to eye". ${ }^{23}$ Siegfried Marquart (born in 1947), a former high-ranking officer of the National People's Army (Nationale Volksarmee), remembered a "fundamental arrogant stupidity", intended to show the "other" (Russian) side that "we were back again". ${ }^{24}$ In the terms of the American sociologist Harold Garfinkel (1956), we may interpret these forms of (direct and indirect) encounters as "rituals of degradation" (for the administrative sphere, see Gravier 2003). These specific transitional rituals were typically associated with a discrediting of the past and thus indicated a revaluation of the past.

As the sociologist Nina Leonhard recently stated, these rituals were a fundamental condition for the negotiation of new identities among former members of the National People's Army after their integration into the Federal Armed Forces in October 1990. In this process, the label "army of unity" was invented (Leonhard 2016: 133-144). At that time, only a small number of soldiers were taken on permanently, which caused additional problems in accepting the new (military and societal) order. The views expressed above came from someone who spoke Russian fluently, spent several years in the Soviet Union, studied at the military academy in Moscow, and thus had countless encounters with Soviet/ Russian (civilian and military) citizens. These individual experiences shaped his perceptual patterns and may explain his feeling of being downgraded. Vice versa, this perceived devaluation most likely strengthened his already close attachment and solidarity with the former "brothers' army" further.

The circumstances of the parting ceremony evoked other notable moments of irritation, which had repercussions for the Wünsdorf locals and their remembrances, too. First, there was a great deal of astonishment over the idea of organizing the farewell ceremony for the Russian troops not as a common event with the British, American, and French military forces, but instead as a singular event held not even in Berlin, but in the National Theater in Weimar. "This is not our place", Matvei Burlakov said angrily, apparently referring to the liberation of the Buchenwald concentration camp in April 1945 by the American army and the following running of the camp by the People's Commissariat for Internal Affairs (Narodnyi Komissariat Vnutrennikh Del, NKVD). Until its 
dissolution in 1950, more than 7,000 people died of starvation, malnutrition, and disease in Special Camp No. 2.

It was not until the Social Democratic Party's (Sozialdemokratische Partei Deutschlands, SPD) leading politicians, including Wolfgang Thierse, Friedrich Schorlemmer, and Manfred Stolpe, sent a letter to Helmut Kohl asking him to change the location so as not to humiliate the Russians, that the chancellor settled on Berlin. Nonetheless, Bundeskanzler Kohl was still against a "joint and equal leaving of all allied forces in Germany" (Kaiser \& Herrmann 2010 [1993]: 185-186). Although according to a survey, 75\% of Germans supported a common celebratory ceremony, the German government opposed this idea, as they too deeply felt the ideological divide (ibid.). "Our soldiers do not leave as occupiers, but as partners and friends," Yeltsin stressed in his speech on August 31, 1994, during the official farewell ceremony in Berlin. But even the highly symbolic joint laying of a wreath at the Soviet memorial in BerlinTreptow and the emotional singing of the specially composed song titled "Lebe wohl, Deutschland, wir reichen dir die Hand" ('Goodbye Germany, We Reach Out Our Hands') could not hide the fact that the day was experienced and remembered as a "second class" leaving (Kaiser \& Herrmann 2010: 185-186). ${ }^{25}$

This symbolic and real distinction is also reflected in the interviews. The majority of the interviewees remembered the ceremonial dimension as being important and dignified because it symbolized gratitude, especially in the context of the Peaceful Revolution in 1989, when the Russian Army remained calm. In general, the interviewees would also have preferred a common ceremony with all four allied forces to prevent the Russian Army from appearing in an outsider role. However, four interviewees explicitly emphasized the importance of holding separate ceremonies. A separate event expressed the "hierarchy" among the occupying forces, with the Red Army being the least respected. Herbert Wüllenweber (born in 1951), who strongly supported separate ceremonies, explained his opinion via a biographical and generational experience: his father had been a front-line soldier on the Eastern Front, fighting against the Soviets. "I am in no way a friend of the Russians," he added, and he also mentioned the overly "arrogant and dolled-up Russian women" (Russenweiber) and not least the current political developments ("I am anything but a Putin whisperer" ${ }^{26}$ ). He clearly demonstrated that the interpretation of the past is always affected by knowledge of the present (Sabrow 2014: 36-37; for the context of the military transition, see Ehlert 2013; Thoß 2007). The feeling of cultural superiority may also have played a central role in retrospective descriptions and the reproduction of pejorative stereotypes like the ones discussed above (von Wrochem 2003: 62; for an overview, see Müller 2005). 
This mixture eventually also shaped the present-day perception and evaluation of Wünsdorf (and its desired future). In general, it is striking how the symbolic space of the former military base was influenced and dominated by a clear dichotomy regarding the images of the Soviets/Russians, which oscillated between idealizing descriptions and demonizing horror stories. While some of the interviewees tended to idealize the time with the Soviets and speak of it as the "most wonderful period of their lives" referring directly to the post-Russian time, which was in their eyes characterized by "disorder, decline, and dirt", and which transformed Wünsdorf into a dead ghost town, others did not even try to conceal their Russophobia. In the interviews, which were by no means free of polemics, a self-referential split was most clearly expressed via external and self-attribution and the categorization of "Russian friend", "whisperer", or "enemy", ${ }^{27}$ which very likely was not only the case in Wünsdorf but also in other former garrison towns, even outside Germany.

A noteworthy differentiation can be concluded regarding 1) the size and importance of Wünsdorf in the military network in the GDR and the whole Eastern bloc and, even more important, 2) the specific context of the reunited German society, which lies transversely to these processes of appropriation and negotiation and, subsequently, the (new/old, visible/invisible, open/subtle) borders which affect memories, narratives, and emotions. In this society different "arenas of transition" happened to occur: conflicting fields that represent problematic, conflictual, and often contradictory processes of merging, identification, and self-understanding (for a first draft of these "arenas", see Großbölting \& Lorke 2017).

As one example of an "arena", the case of Wünsdorf in its (Soviet/Russian) past and present clarifies the overlapping of current and long-lasting conflict situations in different dimensions: the military, political, social, cultural, memorial, collective, and individual. The Wünsdorf case represents not only how the different modes within the GDR past were negotiated repeatedly, but also how encounters with Russians (and references to them) before and after the period of 1989-1994 were highly determined by biographically acquired, available, and activated reservoirs of cultural and national clichés and stereotypes. Yet, there was also a recursiveness in the handling of the individual's past (Gallinat \& Kittel 2009; von Plato 2009) and in the negotiation of GDR and/or East German identity (Pollack \& Pickel 1998), which for many Wünsdorf locals even today is closely interwoven with the Soviet/Russian presence until 1994. 


\section{THE (LASTING) PROCESS OF CONVERSION: WÜNSDORF BETWEEN “HOBBYHORSE” AND “HUMBUG”}

When the last Russian soldier left Wünsdorf in September 1994, ownership of the property was assigned by the state of Brandenburg. The restructuring, renovation, and conversion of former military sites were great challenges financially, logistically, and symbolically. For Brandenburg, above all, the immense size of former military areas was a huge burden: about 120,000 hectares were transferred to the state by the federal government after the withdrawal in June 1994. In comparison to the other four New Länder, Brandenburg was the area most affected by military utilization of land and conversion. Thus, the importance of this task was codified in the Constitution of the Land of Brandenburg (Article 40; "Grund und Boden"). ${ }^{28}$ Quickly, the conversion of this intersection of German, European, and Soviet military history came to be a prestige project, the "hobbyhorse"29 of Prime Minister Manfred Stolpe (SPD), which took place under the heading Von der Konfrontation zur Kooperation ('From Confrontation to Cooperation'). But what can be done with an area six kilometers long and 800 meters wide, with a mix of contaminated soils and sites, approximately three million liters of kerosene, 300,000 tons of waste, ammunition, and a nature reserve, and how can the different layers of the past be integrated within a more or less "consistent" memorial narrative (Kaiser \& Herrmann 2010 [1993]: 204-205; Gießmann 1992: 199-206)?

One of the first major measures, aside from the return of property and houses, and one of the most notable elements of commemoration among the interviewees, was the reopening of federal highway B 96, which had been closed to through traffic since the 1950s. There are reasons why almost all of the interviewees mentioned the reopening. By 1991, several local initiatives had tried to reopen the highway, leading to an ongoing battle between the locals and the Russian troops. More than 1,000 applications arrived in the community's office. Eventually, the Russian commanders refused these requests on the grounds of possible noise pollution and the running out of goods in the Russian shops (Für die Wünsdorfer 1991). According to a journalist's observation, at that time the "German-Russian climate was extremely tense" (Liebold 1991). All the greater was the joy when the highway was eventually opened to public traffic in 1994 . Many interviewees regarded this as a symbolic new beginning, ${ }^{30}$ and one of them even saw it as the "only positive effect of the withdrawal". ${ }^{31}$

The development company Landesentwicklungsgesellschaft (LEG) ${ }^{32}$ had ambitious plans, and in 1993 cited locational factors, such as its close proximity to Berlin, the labor potential, favorable traffic links, and landscape (Wieschollek 2005: 51-62). ${ }^{33}$ Eventually, nine development scenarios were proposed, 

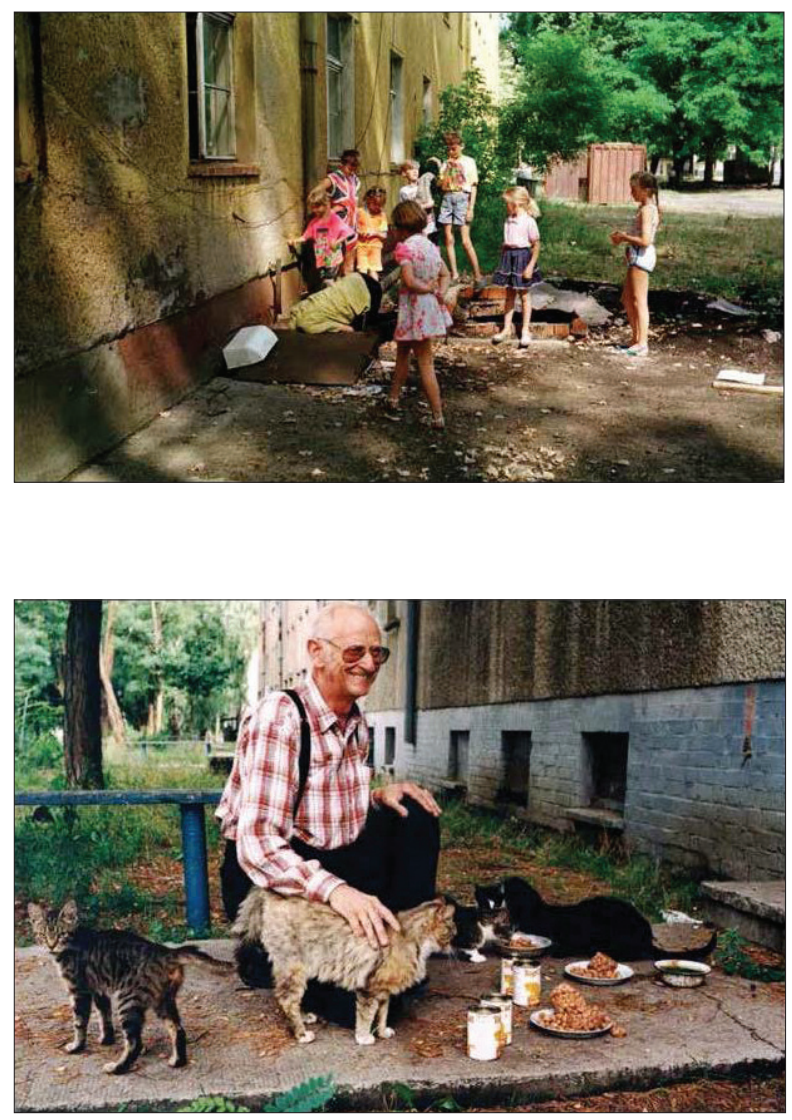

Figure 7-8. Glimpses of Wünsdorf after the withdrawal of Soviet forces in 1994. Garnisonsmuseum Wünsdorf.

ranging from a zero solution (i.e. renaturation), and an eco-city ("Architecture, Ecology, and Art”) to Germany's largest city for refugees (which, according to a documentary, led to many objections from the locals (see Richter 1993)), ${ }^{34}$ a leisure, service, technology, and innovation center like Silicon Valley, and a bureaucratic and satellite town with up to 20,000 inhabitants ("Good Night in Fresh Air”) (Kaiser \& Herrmann 2010 [1993]: 201-202; Brüske 1993; Hénard 1993). In April 1995, there was a cabinet decision to maintain the character of the area and, using the name Waldstadt ('Woody City'), which today is a part of the community of Wünsdorf, create a place for living, trading, administration, education, and working within an attractive environment. Furthermore, eighty million marks in aid money was made immediately available (Wieschollek 2005: 
70). In the end, none of the plans were realized. Considering the unemployment rate of up to $20 \%$ in Wünsdorf in the mid-1990s, the price of commercial spaces was presumably too high. On the other hand, there was no complete breakdown either, not least due to an immense amount of aid money from private initiatives and the European Union. Nowadays, there are approximately 6,500 inhabitants in Wünsdorf, half of whom live in Waldstadt.

By 2009, $80 \%$ of the former military sites had been sold (Kaiser \& Herrmann 2010 [1993]: 204). However, as almost everywhere in East Germany, especially in rural areas, there is still a comparatively high number of empty properties in Wünsdorf, although that number has decreased slightly during the last ten years (for an overview, see Kratz 2003). Additionally, most likely as a strategic decision, the Brandenburg state agency for the road sector and the state office for the preservation of order are based in Wünsdorf and have several hundred employees.

The causes of this situation are complex and multilayered, as well as controversial: unused potential, conflicts over use, the lack of sufficient development, and the premature development of common visions, and missing or overestimated infrastructure are some of the general aspects which were mentioned regularly (Lohnes \& Kucera 1997; Wieschollek 2005: 131-160). Due to high expectations, the term "conversion" often has a negative connotation. In contrast, the interviewees were less squeamish, and they often used such phrases as utopian, unrealistic ideas, fantasies, "humbug", sinister and clandestine machinations and intrigues by third-class incompetent West German professionals, and unfeasible and useless ideas full of lobbying, trickery, and wheeling and dealing in the context of restructuring the former military property. ${ }^{35}$ For some of the interviewees, with the withdrawal of the Russians a part of the imagined GDR past left, too. Such statements may be interpreted as a delimitation of the "new time" and/or of the West Germans and, thus, a reaction to the perceived devaluation of the individual and collective life's work (Müller 2011: 368).

Today, there is a special focus on the touristic potential and European-wide important military history of Wünsdorf related to the Kaiser, Hitler, and the Russians, along with ties to the arts, culture, and nature. In September 1998, the first and only German "book town" was founded here, following a British model, in order to promote humanistic ideas, appreciation of books and the closed bunkers as symbols of peace, and to encourage a sensible approach to the past and present. ${ }^{36}$ The private limited company Bücherstadt-Tourismus GmbH organizes different thematic guided tours through the "Forbidden City", accompanied by campfires, the serving of stew from a field kitchen, military-historical seminars, encounters with military vehicles, an "underground Sunday" in the "zeppelin" signal bunker, and readings. Even though the book town project is regarded as 


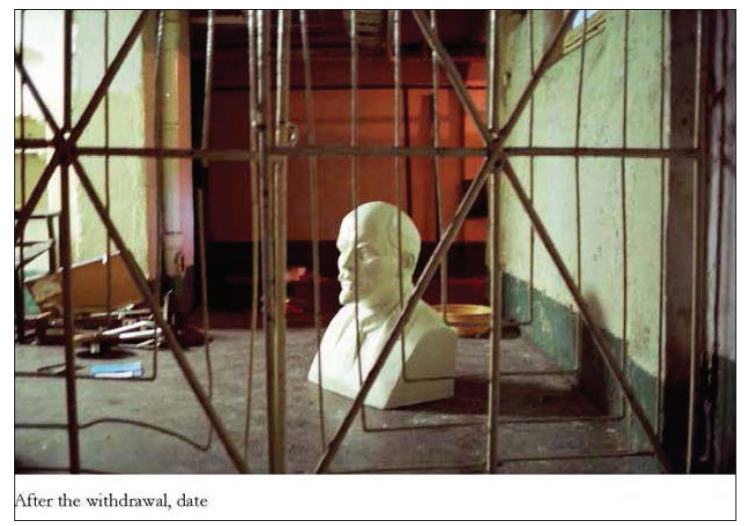

Figure 9-10. Glimpses of Wünsdorf after the withdrawal of Soviet forces in 1994. Garnisonsmuseum Wünsdorf.

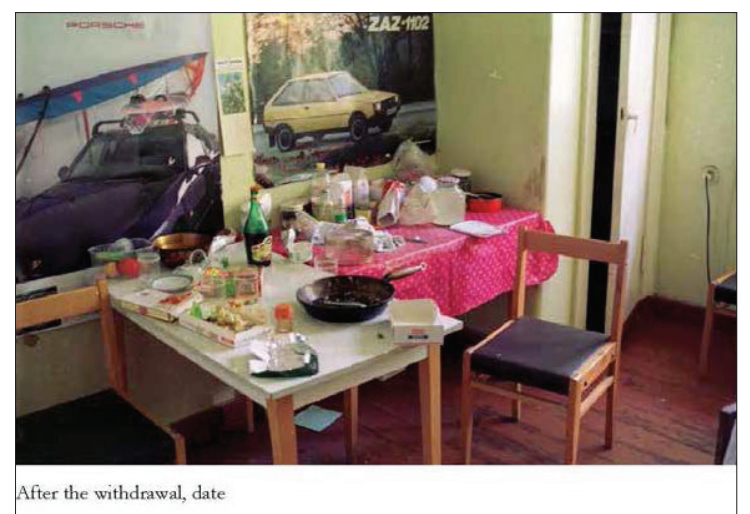

a success (e.g. Arlt 2010: 672), it is in a constant struggle for its existence: of the twenty original antiquarian booksellers, only three have survived, and there are 400,000 books waiting to be sold (Mallwitz 2015). There is also a garrison museum, Roter Stern ('Red Star'), which is supported by a local booster club and gives an interesting but quite uncritical overview of the Soviet/Russian stay in Germany, with both permanent and changing exhibitions showing the didactic and educational efforts to preserve the memory of Wünsdorf's military past (Fischer 2000; 2010).

It is evident that these developments shaped memorial representations as well as the practical aspects of managing the former military past. In Wünsdorf, there are still initiatives to deal with the military heritage in general and the withdrawal of the army in particular. In order to preserve the memory of the Soviet presence, a ring road in Wünsdorf was named after Pjotr Koschewoj, a former Soviet marshal who was based there for several years. The renaming 
Figure 11. A glimpse of Wünsdorf after the withdrawal of Soviet forces in 1994. Garnisonsmuseum Wünsdorf.

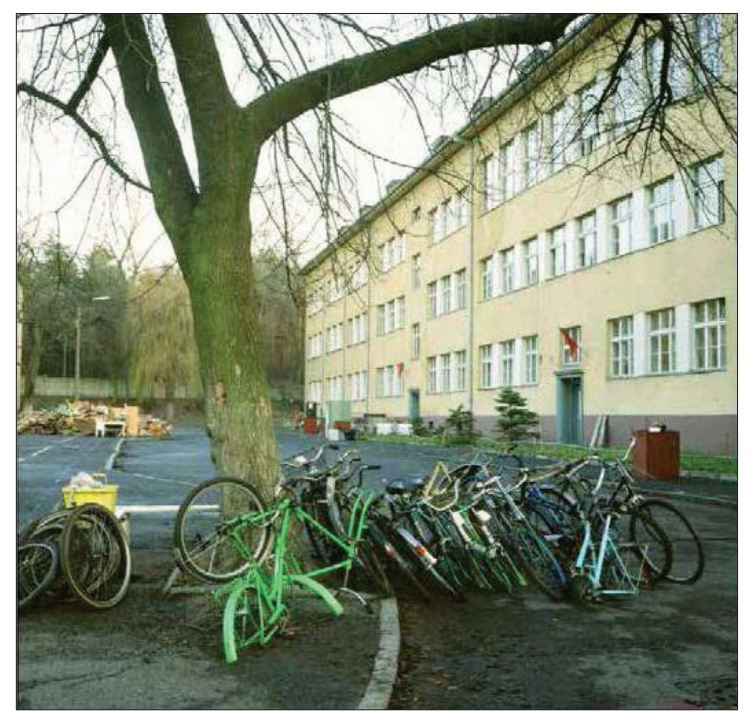

was a response to the failed initiative of the Freunde der Bücherstadt Wüns$\operatorname{dorf}$ ('Friends of the Wünsdorf Book Town') to rename another street after the controversial commander Burlakov (Degener 2014a). As a common initiative of the Bücherstadt Wünsdorf and the Russian embassy, on the 20th anniversary of the withdrawal, in 2014, Anton Terentjew, who was a colonel general in Wünsdorf in 1993 and 1994 and thus played a significant role in the process of the withdrawal, returned and thanked the locals for their "maintenance of tradition" (Die Rückkehr 2014; Degener 2014b). On that day, gratitude for Europe's liberation from fascism was expressed in Wünsdorf, including greetings from local and national politicians, although at that time the conflict between Russia and the Ukraine was underway.

Among Russians, there is significant interest in and willingness to visit Wünsdorf, and especially among the younger generation there is a vibrant online culture of commemoration, for example, in the social medium VK. ${ }^{37}$ The lively exchange of class photographs may not be merely a surrogate for remembering their "homeland", and many plan to visit the place of their childhood as potential "homesick tourists" (provided they have the financial ability to do so). ${ }^{38}$ This specific double perspective was also registered by the locals and emphasized in some of the interviews: for many Russians, Wünsdorf became their "homeland", as Dietrich Meyer (born in 1943) highlighted, and their withdrawal was "tantamount to a catastrophe". ${ }^{39}$ 


\section{CONCLUSION: REINTERPRETING THE MILITARY PAST IN WÜNSDORF}

As discussed above, the permanent presence of Soviets/Russians has left deep traces in Wünsdorf regarding the creation of (new) cultural and spatial, as well as social and individual, identities. The variety of the collective and individual handling of the legacies of the Cold War in Wünsdorf nowadays illustrates different forms of appropriating, updating, reinforcing, neglecting, and excluding certain elements of the Soviet/Russian past. Opinions about the Russians before 1990 are cross-generational and still present today, and they now stretch the full range from anti-Russian sentiments and the commemoration of a highly negative concept of "foreign domination" to feelings of belittlement and continuing melancholy.

This finding corresponds with a survey of East Germans by the Institut für Demoskopie Allensbach ('Allensbach Institute for Public Opinion Research') in 1994, when $32 \%$ of the respondents assessed the Russian troops as "mostly friends and allies", while $42 \%$ regarded them as "mostly an occupying power" (Müller 2011: 144). Even if one concedes that the sample of the present study represents a multiple skewed perspective - those who responded to the press call had "something to say" and a special "need for communication" - the conclusions strengthen the argument presented by historian Evemarie BadstübnerPeters, who claimed that the Soviet (Russian) influence was a constant and highly relevant factor in everyday life, to a far greater extent than assumed previously. Its impact is noticeable even today. The "difficult handling of the difficult foreignness" (Badstübner-Peters 1997a; 1997b) most likely not only influenced behavioral and orientation uncertainties after 1990, in regard to dealing with foreign cultures and lifestyles, but also led to different ways of coming to terms with the past, which reflects a highly ambivalent memorial landscape and current (geo)political and diplomatic developments. These findings can be classified as selected practices of "othering" in terms of a certain space, where "foreignness" can be interpreted as a result of everyday interaction, construction, identification, and irritation. This also reflects on both existing and obsolete ideas of social, economic, cultural and ethnic order within a certain space, and the embedded role of the "foreign" that over many years significantly influenced the local symbolic order (Geenen 2002: 245-247; Reuter 2002).

In terms of the future, many residents place plenty of hope in the completion of a major airport for Berlin. The Waldstadt page advertises a "space for visions", an "exceptional environment", the "best infrastructure and transport link", a place with a historical location, vivid culture, and "enchanting lake 
scenery", which is, however, still in a "deep sleep". The "very low commercial tax rate" and, above all, the proximity to the future Berlin airport would offer "unlimited opportunities". ${ }^{40}$ Many interviewees mentioned this scenario too, and not only the relocation of "noise refugees" (i.e. people escaping the noise of city life), but also the existence of a major Russian investor were mentioned. ${ }^{41}$

Taking a quick glance at its current status, in the past year approximately 1,500 refugees were admitted for the first time to live at the former military base in Wünsdorf (Fischer 2015). In May 2015, two local right-wing youths attacked the complex with fireworks. The local initiative Wünsdorf wehrt sich ('Defending Wünsdorf') organized several demonstrations last autumn, warning against crime, disease, and sexual assault. At the end of the event, the crowd loudly demanded the withdrawal of Chancellor Angela Merkel and sang the national anthem (Brockhausen \& Rohowski 2015). Their Facebook page has more than 3,100 likes (as of September 2017), much more than the 643 likes for the local refugee aid campaign from the same month, and notable statements by their followers include: "I really preferred the Russians much more", or "If only the Russians were still here". Statements like these again powerfully demonstrate how for many locals the unloved past can be updated (and upgraded) when new symbolic hierarchies are required and new borders have to be established. For the time being, the question must remain open, as an interviewee suggested, as to whether some of the residents have difficulties handling any type of foreignness: "Fear of Russians, fear of wolves, fear of refugees - this is a constant feature of Wünsdorf's history". ${ }^{42}$ The last statement indicates a divergent type of "foreignness", which privileges the Soviet/Russian past in Wünsdorf. It again proves that how to deal with former Soviet bases in Germany is strongly influenced by the different layers of the aftermath in the context of the German reunification and the lasting effects of the "power of unofficial memory" (Burke 1991: 300).

\section{ACKNOWLEDGEMENTS}

I would like to thank Sabine Kittel and Lilith Buddensiek for the first, unofficial proofreading. I would also like to thank the anonymous reviewers along with the editors for providing indispensable suggestions on how to more effectively structure this essay. 


\section{NOTES}

1 This was the name beginning in 1988. From 1954 the name was the Group of Soviet Forces in Germany. The Soviets stayed based on the "Treaty on Relations between the USSR and the GDR" (1955).

${ }^{2}$ For a summary of the locations, see the database edited by the Militärgeschichtliches Forschungsamt ('Military History Research Office'), available at http://www.mgfa.de/ html/standorte_einleitung.php, last accessed on August 23, 2017.

3 For example: Altengrabow, Karl-Marx-Stadt, Dresden, Grimma, Halle, Hillersleben, Jena, Magdeburg, Merseburg, Rostock, Schwerin, Stendal, Weimar, or Wittenberg.

${ }^{4}$ Bernau, Cottbus, Dallgow, Eberswalde, Fürstenberg, Jüterbog, Perleberg, Potsdam, Neuruppin, Neustrelitz, Rathenow, or Vogelsang, to name only a few.

5 See the contribution by Evgeny V. Volkov in this volume.

6 In detail: "Märkische Allgemeine”, "Wochenspiegel”, "Blickpunkt", "Teltow-Kanal", "Stadtblatt Zossen", and the homepage of the community of Zossen (available at www. zossen.de, last accessed on August 23, 2017).

7 The questions were: 1) What part did the Soviet troops and the place of Wünsdorf play for you before the year 1989? 2) How would you describe or characterize the "interim phase" between 1989 (the fall of the Berlin Wall) and 1994 (the withdrawal of the troops)? 3) How did you experience the process of withdrawal: the mood in Wünsdorf among the local residents as well as among the soldiers? What has happened to this place since then? These open questions allowed enough space for additional remarks by the interviewees and also for further inquiries on my part.

8 This is not the place to propose a broader discussion of the term "generation". Very briefly, subdividing these people into generations (Ahbe \& Gries 2006), eight interview partners (40\%) belonged to the Aufbau-Generation ("Construction Generation"), born between 1920 and the mid-1930s, seven (35\%) to the funktionierende Generation ("Functioning Generation"), born from the mid-1930s until the end of the 1940s, and five (25\%) to the integrierte Generation ("Integrated Generation"), born in the 1950s. What is important here is the fact that the majority of my interview partners were from the Aufbau- and funktionierende Generation, which shows their interest as well as personal/emotional involvement.

9 The only interviewed woman mentioned that in the context of the end of World War II the locals were "frightened". Interview with Ilse Bollmann (born in 1929), February 26, 2016. To protect their privacy, all names of the interviewees have been fictionalized and created by the author.

${ }^{10}$ Interview with Ilse Bollmann, February 26, 2016.

11 "F" stands for Fernverkehrsstraße; in 1990, the name was changed to B 96 -Bundesstraße ('Federal Highway').

${ }^{12}$ Interview with Gerhard Dombritz, February 18, 2016. 
${ }^{13}$ Only a small selection: Sowjettruppen 1990; Schwelien 1991; Mafia 1991; Unsere Leute 1993; Habbe 1993; Militär 1994; Zwischenbilanz 1994.

${ }^{14}$ Interview with Günther Heisig, February 19, 2016; similar statements were mentioned in the interviews with Walther Meining (born in 1935), March 1, 2016, and Willy Tuchscherer (born in 1932), March 5, 2016.

${ }^{15}$ See, for instance, the following selection of media articles: Furman 1991; Lippold 1991; Schwelien 1991. Resentment was mentioned in detail in one interview, with Gerd Langer (born in 1931), March 3, 2016. These verbal attacks were addressed both to soldiers and the families of higher ranks.

${ }^{16}$ Interviews with Arnold Klein, February 25, 2016, and Bernhard Michel (born in 1939), March 19, 2016.

${ }^{17}$ Interview with Ilse Bollmann, February 26, 2016.

${ }^{18}$ Interviews with Winfried Bläse, March 3, 2016, and Bernhard Michel, March 19, 2016.

${ }^{19}$ For example, in the interviews with Werner Schmidt (born in 1933), February 28, 2016, and Harald Weber (born in 1951), March 3, 2016.

${ }^{20}$ Interview with Heinz Bremer, March 8, 2016; see also Kowalczuk \& Wolle 2010: 223.

${ }^{21}$ Die Russischen Truppen verabschieden sich. ORB, June 11, 1994; 02'20, Deutsches Rundfunarchiv Babelsberg, No. 9400834. See also a short extract available at https:// www.youtube.com/watch?v=ShYQFoh2290, last accessed on August 23, 2017.

${ }^{22}$ Interview with Winfried Bläse, March 3, 2016.

${ }^{23}$ Interview with Walther Meining, March 1, 2016.

${ }^{24}$ Interview with Siegfried Marquardt, March 7, 2016.

${ }^{25}$ See also Staatsfeiern 1994; Hénard 1994; Jelzin-Besuch 1994.

${ }^{26}$ Interview with Herbert Wüllenweber, March 15, 2016.

${ }^{27}$ Interview with Gerhard Dombritz, February 18, 2016.

${ }^{28}$ See https://bravors.brandenburg.de/de/gesetze-212792, last accessed on August 23, 2017.

${ }^{29}$ Hobbyhorse. Märkischen Allgemeine Zeitung. January 25, 2002.

${ }^{30}$ Interview with Walther Meining, March 1, 2016.

${ }^{31}$ Interview with Winfried Bläse, March 3, 2016.

${ }^{32}$ Landesentwicklungsgesellschaft (state development corporation). In June 1995 the LEG, which was operating in deficit, was succeeded by the Entwicklungsgesellschaft Waldstadt Wünsdorf/Zehrensdorf (EWZ). For further background information, see Wieschollek 2005. 
${ }^{33}$ Infrastructural and financial limitations (mainly, being far from Berlin's sphere of influence, a remarkable workforce potential that was concentrated only in a few economic sectors, and a lack of investor interest) were discussed, too.

${ }^{34}$ Following this article, observations could be made that Wünsdorf local residents occasionally stated that foreigners would be the least favorable new neighbors.

${ }^{35}$ Interviews with Günther Heisig (born in 1933), February 19, 2016; Winfried Bläse, March 3, 2016; Herbert Wüllenweber, March 15, 2016; and Bernhard Michel (born in 1939), March 19, 2016.

${ }^{36}$ Bücher und Bunkerstadt Wünsdorf. Bücherstadt-Tourismus GmbH. Available at www. buecherstadt.com, last accessed on August 23, 2017.

${ }^{37}$ For instance, see GSVG $\star \mathrm{ZGV} \star \mathrm{VIuNSDORF} \star$ WUNSDORF $\star$ GDR $\star \mathrm{DDR}$, available at https://new.vk.com/wunsdorf; Vse kto sluzhil v Viunsdorfe GSVG i ZGV (Everyone who served in Wünsdorf in the Group of Soviet Forces in Germany (GSFG) and in the Western Group of Forces (WGF)), available at https://new.vk.com/ club4598721; Shkola 89 GSVG/ZGV Viunsdorf (School No. 89 GSFG/WGF), available at https://new.vk.com/club156004; ZGV. Viunsdorf. Shkola №1 (WGF. Wünsdorf, School No. 1), available at https://new.vk.com/club58542; ZGV Viunsdorf NIKEL' p.p.35714 (WGF Wünsdorf Nikel p.p.35714), available at https://new.vk.com/club1056642; http:// wunsdorf.livejournal.com, all last accessed on August 23, 2017.

${ }^{38}$ Wunsdorf, DDR - Posledniaia osen' / / Letzten Herbst. Available at https://www. youtube.com/watch?v=LEOeTtfCigo, last accessed on August 23, 2017.

${ }^{39}$ Interview with Dietrich Meyer, March 10, 2016.

${ }^{40}$ Die Waldstadt Wünsdorf. Available at http://www.waldstadt-wuensdorf.de, last accessed on August 23, 2017.

${ }^{41}$ Interview with Bernd Holtzschke (born in 1939), March 8, 2016; see also van der Kraat 2014.

${ }^{42}$ Interview with Heinz Küstner (born in 1935), March 8, 2016.

\section{REFERENCES}

Abdullah, Muhammad S. 1984. Halbmond unter dem Preußenadler: Die Geschichte der islamischen Gemeinde in Preußen (1731-1934). Altenberg: Verlag für ChristlichIslamisches Schrifttum.

Abschied in Würde 1994 = Abschied in Würde: Die 'Westgruppe der Truppen' verließ Deutschland. Wehrtechnik, Vol. 26, No. 9, pp. 8-12.

Ahbe, Thomas \& Gries, Rainer 2006. Gesellschaftsgeschichte als Generationengeschichte: Theoretische und methodologische Überlegungen am Beispiel der DDR. In: Annegret Schüle \& Rainer Gries \& Thomas Ahbe (eds.) Die DDR aus generationengeschichtlicher Perspektive: Eine Inventur. Leipzig: Leipziger Universitätsverlag, pp. 475-571. 
Arlt, Kurt 1998. Sowjetische (russische) Truppen in Deutschland (1945-1994). In: Torsten Diedrich \& Hans Ehlert \& Rüdiger Wenzke (eds.) Im Dienste der Partei: Handbuch der bewaffneten Organe der DDR. Berlin: Links, pp. 593-632.

Arlt, Kurt 2010. Zossen. In: Kurt Arlt \& Michael Thomae \& Bruno Thoß (eds.) Militärgeschichtliches Handbuch Brandenburg-Berlin. Berlin: be.bra Wissenschaftsverlag, pp. 666-672.

Assmann, Aleida 2009. Geschichte findet Stadt. In: Moritz Csáky \& Christoph Leitgeb (eds.) Kommunikation - Gedächtnis - Raum: Kulturwissenschaften nach dem 'Spatial Turn'. Bielefeld: Transcript, pp. 13-27.

Assmann, Jan 1997 [1992]. Das kulturelle Gedächtnis: Schrift, Erinnerung und politische Identität in frühen Hochkulturen. München: Beck.

Augé, Marc 1992. Non-Lieux: Introduction à une anthropologie de la surmodernité. Paris: Le Seuil.

Badstübner-Peters, Evemarie 1997a. Über uns und über die 'Russen': Zur Alltagsgeschichte (ost)deutsch-sowjetischer Beziehungen. In: Ludwig Elm \& Dietmar Keller \& Reinhard Mocek (eds.) Ansichten zur Geschichte der DDR, Band 7. Eggersdorf: Verlag Matthias Kirchner, pp 251-275.

Badstübner-Peters, Evemarie 1997b. Ostdeutsche Sowjetunionerfahrungen: Ansichten über Eigenes und Fremdes in der Alltagsgeschichte der DDR. In: Konrad H. Jarausch \& Hannes Siegrist (eds.) Amerikanisierung und Sowjetisierung in Deutschland 1945-1970. Frankfurt am Main \& New York: Campus, pp. 291-311.

Bassistow, Juri W. 1994. Die DDR - ein Blick aus Wünsdorf. Persönliche Eindrücke eines russischen Offiziers. Jahrbuch für historische Kommunismusforschung, pp. 215-224.

Behrends, Jan C. 2003. Sowjetische 'Freunde' und fremde 'Russen'. Deutsch-sowjetische Freundschaft zwischen Ideologie und Alltag (1949-1990). In: Jan C. Behrends \& Thomas Lindenberger \& Patrice G. Poutrus (eds.) Fremde und Fremd-Sein in der DDR: Zu historischen Ursachen der Fremdenfeindlichkeit in Ostdeutschland. Berlin: Metropol, pp. 75-100.

Brockhausen, Stefanie \& Rohowski, Tina 2015. Wünsdorfer stemmen sich gegen 'fanatische Willkommenskultur': Aggressive Stimmung beim Infoabend $\mathrm{zu}$ neuem Flüchtlingsheim. https://www.rbb-online.de/politik/thema/fluechtlinge/ brandenburg/2015/11/buergerversammlung-erstaufnahme-fluechtlinge-zossenwuensdorf.html, last accessed on July 14, 2016; no longer available.

Brüske, Klaus 1993. Nach 100 Jahren endlich zivil: Wünsdorf spielt Nutzungsvarianten für das riesige GUS-Gelände durch. Berliner Zeitung, August 27.

Burke, Peter 1991. Geschichte als soziales Gedächtnis. In: Aleida Assmann \& Dietrich Harth (eds.) Mnemosyne: Formen und Funktionen der kulturellen Erinnerung. Frankfurt am Main: Fischer, pp. 289-304.

Burlakov, Matvei P. 1994. Wirverabschieden uns. Als Freunde:Der Abzug-Aufzeichnungen des Oberkommandierenden der Westtruppe der sowjetischen Streitkräfte. Bonn: InnoVatio-Verlag.

Danyel, Jürgen 2015. Alltag Einheit: Ein Fall fürs Museum! Aus Politik und Zeitgeschichte, Vol. 65, No. 33-34, pp. 26-35.

Degener, Peter 2014a. Sowjet-Marschall als Namenspatron: In Wünsdorf soll eine Umgehungsstraße 'Koschewoi-Ring' heißen. Märkische Allgemeine Zeitung, April 8. 
Degener, Peter 2014b. Festakt mit dem russischen Botschafter: Gedenken an Abzug der russischen Truppen in Wünsdorf. Märkische Allgemeine Zeitung, June 7.

Die Rückkehr 2014 = Die Rückkehr des Stabschefs: Generaloberst Terentjew besuchte das Museum 'Roter Stern'. Märkische Allgemeine, February 7. Available at http:// www.genios.de/presse-archiv/inhalt/MAER/20140207/1/maerkische-allgemeine. html, last accessed on August 24, 2017.

Ehlert, Hans 2013. Abgewickelt - Die Nationale Volksarmee der DDR im Vorfeld der deutschen Einheit. In: Christian Th. Müller \& Matthias Rogg (eds.) Das ist Militärgeschichte! Probleme - Projekte - Perspektiven. Paderborn: Ferdinand Schöningh, pp. 173-190.

Erll, Astrid 2005. Kollektives Gedächtnis und Erinnerungskulturen: Eine Einführung. Stuttgart: Metzler.

Fischer, Oliver 2015. Aufgeheizte Stimmung in Wünsdorf. Märkische Allgemeine Zeitung / Zossener Rundschau, November 27.

Fischer, Silvio 2000. Der frühere Militärstandort Wünsdorf - Ein Ort des Erinnerns? In: Burkhard Assmus \& Hans-Martin Hintz (eds.) Zum Umgang mit historischen Stätten aus der Zeit des Nationalsozialismus. Berlin: Bundesministerium für Bildung und Forschung \& Deutsches Historisches Museum, pp. 129-147.

Fischer, Silvio 2010. Der frühere Militärstandort Wünsdorf: Ein Ort des Erinnerns. Museumsblätter: Mitteilungen des Museumsverbandes Brandenburg, Heft 16, pp. 44-45. Available at http://www.museen-brandenburg.de/fileadmin/pdfs/ Museumsblaetter/Heft_16/k_16_Fischer.pdf, last accessed on August 23, 2017.

Foertsch, Hartmut 1994. Der Abzug russischer Truppen aus Deutschland: 'Keiner sagt: Jungs, kommt bald wieder'. Europäische Sicherheit, Vol. 43, No. 3, pp. 125-127.

Für die Wünsdorfer 1991 = Für die Wünsdorfer bleibt die B 96 weiterhin gesperrt: Gemeindevertreter gaben ihre Passierscheine zurück. Berliner Zeitung, May 18.

Furman, Alexander 1991. Zerrissen ist die russische Seele: Die Sowjetsoldaten leben schlecht zu Hause und einsam in Deutschland. Die Zeit, January 4. Available at http://www.zeit.de/1991/02/zerrissen-ist-die-russische-seele, last accessed on August 23, 2017.

Gallinat, Anselma \& Kittel, Sabine 2009. Zum Umgang mit der DDR-Vergangenheit heute: Ostdeutsche Erfahrungen, Erinnerungen und Identität. In: Thomas Großbölting (ed.) Friedensstaat, Leseland, Sportnation? DDR-Legenden auf dem Prüfstand. Berlin: Links, pp. 304-328.

Garfinkel, Harold 1956. Conditions of Successful Degradation Ceremonies. American Journal of Sociology, Vol. 61, No. 5, pp. 420-424. http://dx.doi.org/10.1086/221800.

Geenen, Elke M. 2002. Soziologie des Fremden: Ein gesellschaftstheoretischer Entwurf. Opladen: Leske \& Budrich.

Gehrke, Thilo 2008. Das Erbe der Sowjetarmee in Deutschland: eine Bild- und Textdokumentation. Berlin: Köster.

Gießmann, Hans-Joachim 1992. Das unliebsame Erbe: Die Auflösung der Militärstruktur der DDR. Baden-Baden: Nomos-Verlag.

Gravier, Magali 2003. Entrer dans l'administration de l'Allemagne unifiée: une approche anthropologique d'un rituel d'intégration (1990-1999). Revue française de science politique, Vol. 53, No. 3, pp. 323-350. Available at https://www.cairn.info/revuefrancaise-de-science-politique-2003-3-page-323.htm, last accessed on August 23, 2017. 
Großbölting, Thomas 2010. Eine zwiespältige Bilanz: Zwanzig Jahre Aufarbeitung der DDR-Vergangenheit im wiedervereinigten Deutschland. In: Thomas Großbölting \& Raj Kollmorgen \& Sascha Möbius \& Rüdiger Schmidt (eds.) Das Ende des Kommunismus: Die Überwindung der Diktaturen in Europa und ihre Folgen. Essen: Klartext-Verlag, pp. 61-75.

Großbölting, Thomas \& Lorke, Christoph (eds.) 2017. Deutschland seit 1990: Wege in die Vereinigungsgesellschaft. Stuttgart: Franz Steiner-Verlag.

Grothusen, Söhnke \& Morais, Vânia \& Stöckmann, Hagen (eds.) 2014. Generation und Raum: Zur symbolischen Ortsbezogenheit generationeller Dynamiken. Göttingen: Wallstein.

Habbe, Christian 1993. Jottwehdeh und Zaun drum. Spiegel Special, February 1. Available at http://www.spiegel.de/spiegel/spiegelspecial/d-52535779.html, last accessed on August 23, 2017.

Hénard, Jaqueline 1993. Allerlei Ideen für die Zukunft Wünsdorfs: Hauptquartier der Russen bei Berlin. Frankfurter Allgemeine Zeitung, July 16.

Hénard, Jacqueline 1994. Der Abschied der Alliierten aus Berlin hat schon begonnen. Frankfurter Allgemeine Zeitung, March 19.

Hoffmann, Hans-Albert \& Stoof, Siegfried 2013. Sowjetische Truppen in Deutschland und ihr Haupt-quartier in Wünsdorf 1945-1994: Geschichte, Fakten, Hintergründe. Berlin: Köster.

Höpp, Gerhard 1997. Muslime in der Mark: Als Kriegsgefangene und Internierte in Wünsdorf und Zossen, 1914-1924. Berlin: Das Arabische Buch.

Jelzin-Besuch 1994 = Jelzin-Besuch: Gute Nacht! Hände hoch! Der Spiegel, May 9. Available at http://www.spiegel.de/spiegel/print/d-13855499.html, last accessed on August 24, 2017.

Kaiser, Gerhard 1998. Sperrgebiet: Die geheimen Kommandozentralen in Wünsdorf seit 1871. Berlin: Links.

Kaiser, Gerhard \& Herrmann, Bernd 2010 [1993]. Vom Sperrgebiet zur Waldstadt: Die Geschichte der geheimen Kommandozentralen in Wünsdorf und Umgebung. Berlin: Links.

Kampe, Hans G. 2009. Das Oberkommando der GSSD in Zossen-Wünsdorf: Zentrum der sowjetischen/russischen Militärpolitik in der DDR. Berlin: Hoppegarten, Projekt + Verlag Dr. Erwin Meißler.

Keller, Reiner 2016. Die symbolische Konstruktion von Räumen: Sozialkonstruktivistischdiskursanalytische Perspektiven. In: Gabriela B. Christmann (ed.) Zur kommunikativen Konstruktion von Räumen: Theoretische Konzepte und empirische Analysen. Wiesbaden: Springer, pp. 55-78. Available at http://www.springer.com/ de/book/9783658008666, last accessed on August 24, 2017.

Kollmorgen, Raj 2010. Diskurse der deutschen Einheit. Aus Politik und Zeitgeschichte, Vol. 60, Nos. 30-31, pp. 6-13. Available at http://www.bpb.de/shop/zeitschriften/ apuz/32599/deutsche-einheit, last accessed on August 24, 2017.

König, Ewald 2010. Burlakows Westgruppe und der Osten. Available at http://www. euractiv.de/section/wahlen-und-macht/news/burlakows-westgruppe-und-derosten/, last accessed on August 24, 2017.

Kowalczuk, Ilko-Sascha \& Wolle, Stefan 2010. Roter Stern über Deutschland: Sowjetische Truppen in der DDR. Berlin: Links. 
Kraat, Marion van der 2014. Vor Sperrgebiet zum Alltag: Wünsdorfs schwieriges Erbe. 20 Jahre nach dem Abzug der sowjetischen Streitkräfte ringt die "verbotene Stadt" um ihre Zukunft. Märkische Allgemeine, August 29. Available at http:// www.genios.de/presse-archiv/artikel/MAER/20140829/vom-sperrgebiet-zumalltag-wuensdor/201408293834714.html, last accessed on September 28, 2017.

Kratz, Walther 2003. Konversion in Ostdeutschland: Die militärischen Liegenschaften der abgezogenen Sowjetischen Streitkräfte, ihre Erforschung, Sanierung und Umwidmung. Berlin: Trafo.

Leonhard, Nina 2016. Integration und Gedächtnis: NVA-Offiziere im vereinigten Deutschland. Konstanz: UVK.

Leydesdorff, Selma 1996. Gender and Memory. Oxford: Oxford University Press.

Liebold, Edda 1991. Jenseits der grauen Mauer: Die Rote Armee bläst zum Abmarsch eine alte Garnison ordnet sich neu. Die Zeit, June 21. Available at http://www. zeit.de/1991/26/jenseits-der-grauen-mauer, last accessed on August 24, 2017.

Lippold, Frank E. 1991. Im Schnelldurchlauf durch Küche und Quartiere: Bundesverteidigungsminister Stoltenberg bei Westgruppe der sowjetischen Truppen. Berliner Zeitung, April 27.

Locke, Stefan 2014. Niemand geht so ganz. Die Zeit, March 27. Available at http://www. zeit.de/2014/14/russen-soldaten-abzug-ddr, last accessed on August 24, 2017.

Lohnes, Patricia \& Kucera, Katerina 1997. Konversion ehemalig militärisch genutzter Liegenschaften in den neuen Bundesländern - am Beispiel des Militärstandortes Wünsdorf. Diploma thesis, University of Kaiserslautern, Germany.

Loth, Wilfried 1998. Stalin's Unwanted Child: The Soviet Union, the German Question, and the Founding of the GDR. London: Palgrave Macmillan. DOI: 10.1007/9781-349-26400-1.

Mafia 1991 = Mafia: Schweigen oder sterben. Der Spiegel, November 4. Available at http:// www.spiegel.de/spiegel/print/d-13490911.html, last accessed on August 24, 2017.

Mallwitz, Gudrun 2015. Einstige Russen-Stadt soll 1200 Flüchtlinge aufnehmen. Berliner Morgenpost, June 14. Available at https://www.morgenpost.de/brandenburg/ article142469462/Einstige-Russen-Stadt-soll-1200-Fluechtlinge-aufnehmen. html, last accessed on August 24, 2017.

Militär 1994 = Militär: Leichen im See. Der Spiegel, January 24. Available at http:// www.spiegel.de/spiegel/print/d-9275411.html, last accessed on August 24, 2017.

Möhring, Maren 2012. Fremdes Essen: Die Geschichte der ausländischen Gastronomie in der Bundesrepublik Deutschland. München: Oldenbourg.

Müller, Christian Th. 2005. 'O' Sowjetmensch! Beziehungen von sowjetischen Streitkräften und DDR-Gesellschaft zwischen Ritual und Alltag. In: Christian Th. Müller \& Patrice G. Poutrus (eds.) Ankunft - Alltag - Ausreise: Migration und interkulturelle Begegnung in der DDR-Gesellschaft. Köln \& Weimar \& Wien: Böhlau, pp. 17-134.

Müller, Christian Th. 2011. US-Truppen und Sowjetarmee in Deutschland: Erfahrungen, Beziehungen, Konflikte im Vergleich. Paderborn: Ferdinand Schöningh.

Naumann, Klaus 1996 [1993]. NVA: Anspruch und Wirklichkeit nach ausgewählten Dokumenten. Hamburg \& Berlin \& Bonn: Mittler.

Nawrocki, Joachim 1994. Abschied in Würde, Ankunft in Armut. Die Zeit, February 18. Available at http://www.zeit.de/1994/08/abschied-in-wuerde-ankunft-in-armut, last accessed on August 24, 2017. 
Obertreis, Julia \& Stephan, Anke (eds.) 2009. Erinnerungen nach der Wende: Oral History und (post)sozialistische Gesellschaften. Essen: Klartext.

Plato, Alexander von 2009. Oral History nach politischen Systembrüchen. Erfahrungen in Deutschland Ost und West: Einige Annäherungen. In: Julia Obertreis \& Anke Stephan (eds.) Erinnerungen nach der Wende: Oral History und (post)sozialistische Gesellschaften. Erinnerungen. Essen: Klartext, pp. 63-82.

Pollack, Detlef \& Pickel, Gert 1998. Die ostdeutsche Identität - Erbe des DDR-Sozialismus oder Produkt der Wiedervereinigung? Die Einstellung der Ostdeutschen zu sozialer Ungleichheit und Demokratie. Aus Politik und Zeitgeschichte, Nos. 41-42, pp. 9-23.

Reuter, Julia 2002. Ordnungen des Anderen: Zum Problem des Eigenen in der Soziologie des Fremden. Bielefeld: Transcript-Verlag.

Richter, Stefan 1993. Für Lenin ist es in Wünsdorf längst nach zwölf: Nach dem Abzug der Russen steht eine 2 700-Seelen-Gemeinde vor dem Problem, einen Militärriesen zu zivilisieren. Berliner Zeitung, September 4.

Sabrow, Martin 2012. 'Fußnote der Geschichte', 'Kuscheldiktatur' oder 'Unrechtsstaat'? Die Geschichte der DDR zwischen Wissenschaft, Politik und Öffentlichkeit. In: Katrin Hammerstein \& Jan Scheunemann (eds.) Die Musealisierung der DDR: Wege, Möglichkeiten und Grenzen der Darstellung von Zeitgeschichte in stadt- und regionalgeschichtlichen Museen. Berlin: Metropol-Verlag, pp. 13-24.

Sabrow, Martin 2014. Die DDR zwischen Geschichte und Gedächtnis. In: Christian Ernst (ed.) Geschichte im Dialog: DDR-Zeitzeugen in Geschichtskultur und Bildungspraxis. Schwalbach: Wochenschau-Verlag, pp. 23-37.

Satjukow, Silke 2004. Sowjetische Streitkräfte und DDR-Bevölkerung: Kursorische Phänomenologie einer Beziehungsgeschichte. In: Hans Ehlert \& Matthias Rogg (eds.) Militär, Staat und Gesellschaft in der DDR: Forschungsfelder, Ergebnisse, Perspektiven. Berlin: Links, pp. 225-249.

Satjukow, Silke (ed.) 2005. 'Die Russen kommen!' Erinnerungen an sowjetische Soldaten 1945-1992. Erfurt: Landeszentrale für politische Bildung Thüringen.

Satjukow, Silke 2008. Besatzer: 'die Russen' in Deutschland 1945-1994. Göttingen: Vandenhoeck \& Ruprecht.

Satjukow, Silke 2009. Die 'Freunde'. In: Martin Sabrow (ed.) Erinnerungsorte der DDR. München: Beck, pp. 55-67.

Schwelien, Michael 1991. Lieber reich als ruhmreich: Nichts fürchten die Sowjetsoldaten mehr als den raschen Marschbefehl nach Hause. Die Zeit, July 5. Available at http://www.zeit.de/1991/28/lieber-reich-als-ruhmreich, last accessed on August 24, 2017.

Sörensen, Marie L. S. \& Viejo-Rose, Dacia (eds.) 2015. War and Cultural Heritage: Biographies of Place. Cambridge: Cambridge University Press. Available at http://www.academia.edu/11723150/War_and_Cultural_Heritage_Biographies_ of_Place, last accessed on August 24, 2017.

Sowjettruppen 1990 = Sowjettruppen: Nerz und Matsch. Der Spiegel, December 24. Available at http://www.spiegel.de/spiegel/print/d-13503061.html, last accessed on August 24, 2017.

Staatsfeiern 1994 = Staatsfeiern: Die unendliche Geschichte. Der Spiegel, March 14. Available at http://www.spiegel.de/spiegel/print/d-13685769.html, last accessed on August 24, 2017. 
Thoß, Bruno (ed.) 2007. Die Geschichte der NVA aus der Sicht des Zeitzeugen und des Historikers. Potsdam: Militärgeschichtliches Forschungsamt.

Tuchman, Barbara W. 1964. Can History Be Served Up Hot? New York Times, March 8. Available at http://www.nytimes.com/1964/03/08/can-history-be-served-up-hot. html, last accessed on August 24, 2017.

Tunbridge, John E. \& Ashworth, Gregory J. (eds.) 1996. Dissonant Heritage: The Management of the Past as a Resource in Conflict. Chichester: Wiley.

Unsere Leute 1993 = Unsere Leute sind aggressiver: Spiegel-Interview mit Sicherheitsoffizier Anatolij Olejnikow über die GUS-Kriminalität in Deutschland. Der Spiegel, June 21. Available at http://magazin.spiegel.de/EpubDelivery/spiegel/pdf/13683264, last accessed on August 24, 2017.

Veblen, Thorstein 1899. The Theory of the Leisure Class: An Economic Study in the Evolution of Institutions. New York: Macmillan. Available at http://moglen.law. columbia.edu/LCS/theoryleisureclass.pdf, last accessed on August 24, 2017.

Welzer, Harald 2002. Das kommunikative Gedächtnis: Eine Theorie der Erinnerung. München: Beck-Verlag.

Wieschollek, Stefan 2005. Ein totgeborenes Kind in Wünsdorf-Waldstadt? Probleme der Umnutzung des ehemaligen Hauptquartiers der Westgruppe der Truppen zur zivilen Kleinstadt. Bonn: Bonn International Center for Conversion. Available at https://www.bicc.de/uploads/tx_bicctools/paper49.pdf, last accessed on August 24, 2017.

Wrochem, Oliver von 2003. Die sowjetischen Besatzer: Konstruktionen des Fremden in der lebensgeschichtlichen Erinnerung. In: Jan C. Behrends \& Thomas Lindenberger \& Patrice G. Poutrus (eds.) Fremde und Fremd-Sein in der DDR. $\mathrm{Zu}$ historischen Ursachen der Fremdenfeindlichkeit in Ostdeutschland. Berlin: Metropol, pp. 57-74.

Zwischenbilanz 1994 = Zwischenbilanz des russischen Abzugs: Verzögerungen beim Wohnungsbau/Zunehmende Kriminalität. Frankfurter Allgemeine Zeitung, January 26. Available at http://www.genios.de/presse-archiv/inhalt/ FAZ/19940126/4/f-a-z-frankfurter-allgemeine-zeitung.html, last accessed on August 24, 2017.

\section{INTERNET SOURCES}

Bücher und Bunkerstadt Wünsdorf. Bücherstadt-Tourismus GmbH. Available at www. buecherstadt.com, last accessed on August 23, 2017.

Die Waldstadt Wünsdorf. Available at http://www.waldstadt-wuensdorf.de, last accessed on August 23, 2017.

Militärparade in Wünsdorf 1994. Available at https://www.youtube.com/ watch?v=ShYQFoh2290, last accessed on August 23, 2017.

Stadt Zossen. Available at www.zossen.de, last accessed on August 23, 2017.

$V K$ (social medium). Available at https://new.vk.com/wunsdorf, last accessed on August 23, 2017.

Wunsdorf, DDR-Posledniaia osen' / / Letzten Herbst. Available at https://www.youtube. com/watch?v=LEOeTtfCigo, last accessed on August 23, 2017. 